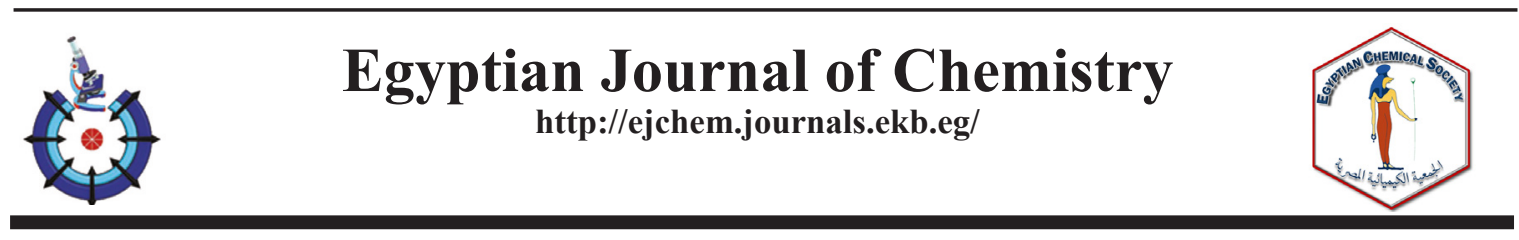

\title{
Optical Properties of Thin-film Hybrid Organic-inorganic Perovskites under The Influence of Pyridine Vapor
}

\author{
Tatyana Yu. Zelenyak ${ }^{1}$, Vladislav A. Kinev ${ }^{1}$, Snezhana I. Fokina', Pavel. P. \\ Gladyshev $^{1^{*}}$ and Medhat A. Ibrahim ${ }^{2}$ \\ ${ }^{1}$ Dubna State University, 19 University Str., Dubna, 141980, Moscow region, Russian \\ Federation. \\ ${ }^{2}$ Spectroscopy Department, National Research Centre, 33 El-Bohouth St., 12622, \\ Dokki, Giza, Egypt.
}

\begin{abstract}
$\mathbf{P}$ EROVSKITE solar cells (PSC) attracted much attention due to their excellent optoelectronic characteristics and efficiency reached $24.2 \%$ only in the last few years. Despite their high efficiency, there is still a limited stability of the PSC, which must be overcome. It was recognized that a humid environment and oxygen is the main problem in the decomposition of perovskite materials. This article is devoted to the study of the perovskite thin films stability by treating the surface with pyridine. Perovskite samples were studied by UVVisspectroscopy as well as FTIR spectroscopy. FTIR indicated a slight change in the structure of perovskite films. While no damage under the action of pyridine was detected, the material retained its semiconductor properties. It is concluded that increasing the long-term stability of organo-inorganic perovskites requires further research.
\end{abstract}

Keywords: Hybrid perovskite, Pyridine treatment, UV-Vis and FTIR.

\section{Introduction}

The appearance of photoelectric converters based on hybrid organic-inorganic semiconductor materials with a perovskite structure (HOIP) of $\mathrm{ABX}_{3}$ was an unexpected breakthrough in the field of third-generation photovoltaics. This class attracted attention due to its excellent optoelectronic characteristics, including wide spectral absorption, low binding energy of excitons, high mobility of charge carriers and a significant diffusion length of charge [1-4]. The main advantage of perovskite materials is that they consist of inexpensive and easily accessible components. Perovskite solar cells also can be formed by low-temperature wet technologies, including printing methods. To date, the efficiency of perovskite solar cells is $24.2 \%$ [5]. However, one of the main problems for the practical application of HOIP in photovoltaics is the low stability in actual operating conditions.
Perovskite materials are rather easily destroying when interacting with water, oxygen, as well as during heating and prolonged illumination [6-9].

It is reported [10] about the possibility of reducing nonradiative electron - hole recombination in perovskite $\mathrm{CH}_{3} \mathrm{NH}_{3} \mathrm{PbI}_{3}$ by treating the surface with pyridine, which allows to increase the photoluminescence (PL) lifetime, which increases by almost an order of magnitude, up to $2 \mu \mathrm{s}$. It is assumed that this is due to the electron passivation of uncoordinated $\mathrm{Pb}$ atoms in the crystal. Thanks to this method, the researchers managed to increase the efficiency of their solar cell from $13 \%$ to $15.3 \%$.

However, treatment with pyridine may be accompanied by undesirable effects, one of which is the formation of a new phase, which manifests itself in the photoluminescence (PL) spectra [11]. Nevertheless, there is still not enough information on the mechanisms of the effect of pyridine on the properties of organic-inorganic perovskites.

*Corresponding author e-mail: pglad@yandex.ru

Received 28/2/2019; Accepted 17/5/2019

DOI: $10.21608 /$ ejchem.2019.12767.1796

(C) 2019 National Information and Documentation Center (NIDOC) 
It is important to note that the stability of the perovskite structure is mainly determined by the Goldschmidt tolerance factor (t) and the octahedral coefficient $(\mu)$. Goldschmidt's tolerance coefficient $(t)$ is calculated from the ionic radii of the atoms, according to:

$$
t=\frac{r_{A}+r_{X}}{\sqrt{2\left(r_{B}+r_{X}\right)}}
$$

where $r_{A}$ - the radius of the cation $\mathrm{A}, r_{B}$ - the radius of the cation $\mathrm{B}, r_{X}-$ the radius of the anion $\mathrm{X}$.

The octahedral coefficient $(\mu)$ is an augmented parameter $\left(\mu=r_{B} / r_{X}\right)$ to confirm the formation of the perovskite structure. In stable structures (t) usually ranges from 0.813 to 1.107 , and $(\mu)$ is 0.442-0.895 during the formation of a stable cubic structure of perovskite [26]. Lead methyl ammonium triiodide $\mathrm{CH}_{3} \mathrm{NH}_{3} \mathrm{PbI}_{3}$ is currently the most widely used material in PSCs, and its $\mathrm{t}$ is $0.834\left(\mathrm{r}_{\mathrm{A}}=1.8 \AA, \mathrm{r}_{\mathrm{B}}=1.19 \AA, \mathrm{r}_{\mathrm{X}}=2.2 \AA\right)$. It can be regulated by replacing or introducing ions of different sizes to obtain a more stable perovskite structure [12].

\section{Materials and Methods}

To obtain the perovskite film $\mathrm{CH}_{3} \mathrm{NH}_{3} \mathrm{PbI}_{3}$, the methyl ammonium iodide salt $\mathrm{CH}_{3} \mathrm{NH}_{3} \mathrm{I}$ was synthesized [13]. The synthesis was carried out by the interaction of methylamine $\mathrm{CH}_{3} \mathrm{NH}_{2}(27.8 \mathrm{ml}$ of aqueous, 40 wt.\%) And hydroiodic acid HI (30 $\mathrm{ml}$ of aqueous, $57 \mathrm{wt} \%$ ) at $0^{\circ} \mathrm{C}$ for 2 hours with constant stirring.

$$
\mathrm{CH}_{3} \mathrm{NH}_{2}+\mathrm{HI}_{2} \rightarrow \mathrm{CH}_{3} \mathrm{NH}_{3} \mathrm{I}
$$

The substance crystallizes by removing the solvent in a vacuum rotary evaporator. The precipitate is washed three times in diethyl ether $\mathrm{C}_{4} \mathrm{H}_{10} \mathrm{O}$ for 30 minutes and filtered on a Schott filter to obtain a precipitate in the form of white crystals. The resulting powder is dried in vacuum at $60{ }^{\circ} \mathrm{C}$ for 24 hours. The remaining reagents needed for the experiment were purchased from Sigma Aldrich.

Thin films of $\mathrm{CH}_{3} \mathrm{NH}_{3} \mathrm{PbI}_{3}$ were obtained by the single-stage method from the precursors $\mathrm{PbI}_{2}$ and $\mathrm{CH}_{3} \mathrm{NH}_{3} \mathrm{I}$ in an anhydrous solvent $\mathrm{N}$,

Egypt. J. Chem. Special Issue (2019)
N-dimethylformamide (DMF, $\mathrm{C}_{3} \mathrm{H}_{7} \mathrm{NO}$ ) in a ratio of 1: 1. The precursor solution was applied by spin-coating on glass slides of $10 \times 10 \mathrm{~mm}^{2}$. After the formation of perovskite films, samples of $\mathrm{CH}_{3} \mathrm{NH}_{3} \mathrm{PbI}_{3}$ were annealed for 10 minutes at a temperature of $120^{\circ} \mathrm{C}$. The experiment was conducted in a glove box in an argon atmosphere $(<0.1 / 0.6 \mathrm{PPm} \mathrm{T}=303 \mathrm{~K})$. Then part of the samples was treated with pyridine vapor for one hour at room temperature $\left(24{ }^{\circ} \mathrm{C}\right)$ in air in a desiccator.

\section{Absorption spectra}

The absorption spectra of perovskite thin films of $\mathrm{CH}_{3} \mathrm{NH}_{3} \mathrm{PbI}_{3}$ were recorded on a spectrophotometer Specs SSP 705 in the wavelength range of 190-1100 nm.

The samples were studied by the method of infrared spectroscopy on a Shimadzu IRAffinity$1 \mathrm{~S}$ instrument with the addition of a single disturbed total internal reflection in the range of $600-4000 \mathrm{~cm}^{-1}$.

\section{Results and Discussion}

The characteristic absorption spectra of the perovskite thin-film structure of $\mathrm{CH}_{3} \mathrm{NH}_{3} \mathrm{PbI}_{3}$ are presented in Fig. 1. There is a sharp decrease in the region of large wavelengths of 780-800 nm, which indicates the formation of a semiconductor with intrinsic conductivity. This conclusion is based on the fact that the intrinsic or fundamental absorption of light in semiconductors is characteristic of the substance, since it is determined by the band structure.

The observed shift of the absorption spectra upward for thin films of $\mathrm{CH}_{3} \mathrm{NH}_{3} \mathrm{PbI}_{3}$ is associated with a large light scattering of the film perovskite structure. It should be noted that the absorption slightly varies with wavelength and represents a smooth curve with a slight bend in the region of $780-800 \mathrm{~nm}$, which is characteristic spectrum of the perovskite structure $\mathrm{CH}_{3} \mathrm{NH}_{3} \mathrm{PbI}_{3}$. This is due to the poor crystallinity of the perovskite thin film caused by the very rapid evaporation of a small amount of a highly volatile DMF solvent (a perfect perovskite structure does not have time to form). 

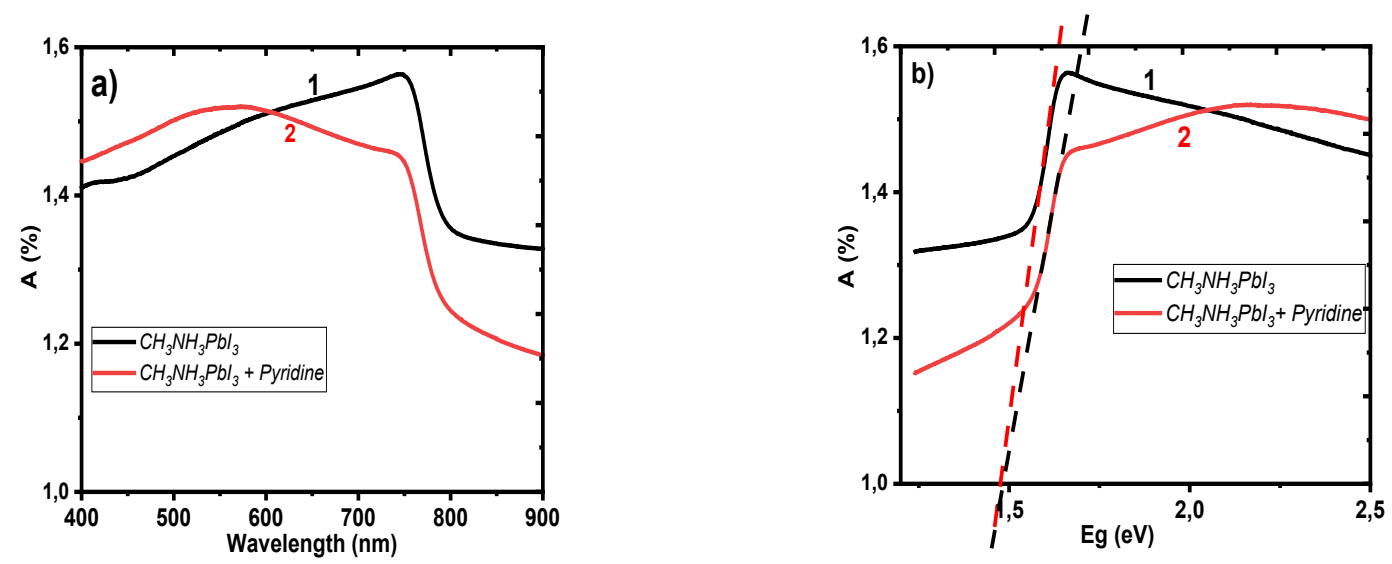

Fig. 1. Absorption spectra of perovskite thin film $\mathrm{CH}_{3} \mathrm{NH}_{3} \mathrm{PbI}_{3}$ (a) and band gap (b) (1 - without treatment, 2 treated with pyridine pairs).

For the practical application of this method of treatment with pyridine vapor organic-inorganic perovskites, it is necessary to understand the mechanisms of interaction of pyridine with the surface and in the bulk of the perovskite crystal. In [10] it was postulated that the interaction of pyridine is limited to the crystal surface. It is assumed that the change in the surface properties of the organo-inorganic perovskite when interacting with the Lewis bases is associated with the electron passivation of uncoordinated $\mathrm{Pb}$ atoms on the crystal surface. This forms a coordination bond between the pyridine nitrogen atom and uncoordinated lead atoms in perovskite. It is believed that the processing of organicinorganic perovskite films with Lewis bases can provide a more controlled and effective method for passivating defective states, especially when the material is processed in an inert atmosphere.

In contrast to [10], it was shown in [14] that pyridine and its derivatives penetrate into the bulk of crystals of organic-inorganic perovskites and may violate the original structure of perovskite crystals, thus the new phases appear. These differences in the behavior of perovskites under the action of pyridine can be associated with different conditions of the interaction process. On the basis of X-ray phase analysis and infrared spectroscopy, the following scheme of the process of degradation of the initial perovskite was proposed [14].

$$
\underset{\mathrm{CH}_{3} \mathrm{NH}_{3} \mathrm{I} .}{\mathrm{CH}_{3} \mathrm{NH}_{3} \mathrm{PbI}_{3}+x \text { pyridine }} \underset{\left.\mathrm{PbI}_{2}-\text { (pyridine) }\right)_{x}+}{+}
$$

This scheme means that the weaker base pyridine $(\mathrm{pKa}=5.30)$ displaces the stronger base methylamine from the perovskite $(\mathrm{pKa}=$ 10.62). At first glance, such a process is unlikely. However, these $\mathrm{pKa}$ values are related to aqueous solutions and differences in $\mathrm{pKa}$ are associated with relatively strong solvation of methylamine. In the gas phase the affinity of pyridine to the proton is close to the affinity to the proton of aliphatic amines $[15,16]$. Such a difference is associated with the possibility of mesomeric delocalization of a positive charge in the pyridine cation, as a result of which the hydration energy decreases [15, 17]. It should be considered that the significantly higher volatility of methylamine $\left(\mathrm{bp}=-6.32{ }^{\circ} \mathrm{C}\right)$ compared with pyridine $\left(\mathrm{bp}=115.6^{\circ} \mathrm{C}\right)$, which can shift the equilibrium to the right.

The exact mechanism of passivation of organic-inorganic perovskite films remains to be clarified. In this case, it is possible that in addition to the formation of a pyridine complex with a cation of lead with the participation of an unshared electron pair of nitrogen, we can expect the formation of $\pi$-complexes of pyridine with metal ions like the complexes of benzene. Although it is believed that this is not typical of pyridine, it was shown [15] that tetravalent lead cations form such complexes. Thus, the refinement of the mechanisms of interaction of pyridines with organic-inorganic perovskites requires additional in-depth studies.

To determine the stability of perovskite based on the addition of pyridine $\mathrm{C}_{2} \mathrm{H}_{5} \mathrm{~N}$. The Goldschmidt tolerance coefficient (t) was calculated for pyridine, which is $0.99\left(\mathrm{r}_{\mathrm{A}}=2.55 \AA\right.$, $\left.\mathrm{r}_{\mathrm{B}}=1.19 \AA, \mathrm{r}_{\mathrm{X}}=2.2 \AA\right)$, for TBP $1.14\left(\mathrm{r}_{\mathrm{A}}=3.25 \AA\right.$, $\left.\mathrm{r}_{\mathrm{B}}=1.19 \AA, \mathrm{r}_{\mathrm{X}}=2.2 \AA\right), 4-\mathrm{Py} 1.46\left(\mathrm{r}_{\mathrm{A}}=4.87 \AA, \mathrm{r}_{\mathrm{B}}\right.$ $\left.=1.19 \AA, \mathrm{r}_{\mathrm{X}}=2.2 \AA\right)$ and for 2-Py $1.86\left(\mathrm{r}_{\mathrm{A}}=6.45\right.$ $\left.\AA, r_{B}=1.19 \AA, r_{X}=2.2 \AA\right)$. With an increase in the size of pyridine derivatives (Fig. 2) and in the sizes of pyridinium derivative cations, it becomes difficult to embed these chemical particles in the perovskite structure. The gradual diffusion of pyridine-based additives into the perovskite layer Egypt. J. Chem. Special Issue (2019) 
entails a chemical change in the initial perovskite structure. A pyridine additive with a long alkyl chain substituted at the o-position can protect the surface of the material from corrosion. It can be assumed that they close the upper perovskite layer or form complexes with $\mathrm{PbI}_{2}$ at the interface of the perovskite/HTM layer. It was believed that initially pyridine supplements were colloidal mainly in the HTM layer or at the perovskite/ HTM interface. As the molecules diffuse into the perovskite layer, the perovskite/HTM interface and the grain boundaries become very susceptible to attack and form a complex. [14].<smiles>c1ccncc1</smiles>

Pyridine

\section{Pyridine based Additives}<smiles>CC(C)(C)c1ccncc1</smiles>

TBP<smiles>CCCCc1ccncc1</smiles>

4-Py

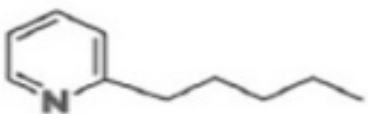

2-Py

Fig. 2. Pyridine-based chemical additives. [14]

The infrared spectra of perovskite films $\mathrm{CH}_{3} \mathrm{NH}_{3} \mathrm{PbI}_{3}$ were obtained before and after treatment with pyridine vapors (Fig. 3) on a
Shimadzu IRAffinity-1S FTIR spectrometer. The spectra obtained correspond to literary data [18] (Fig. 4).

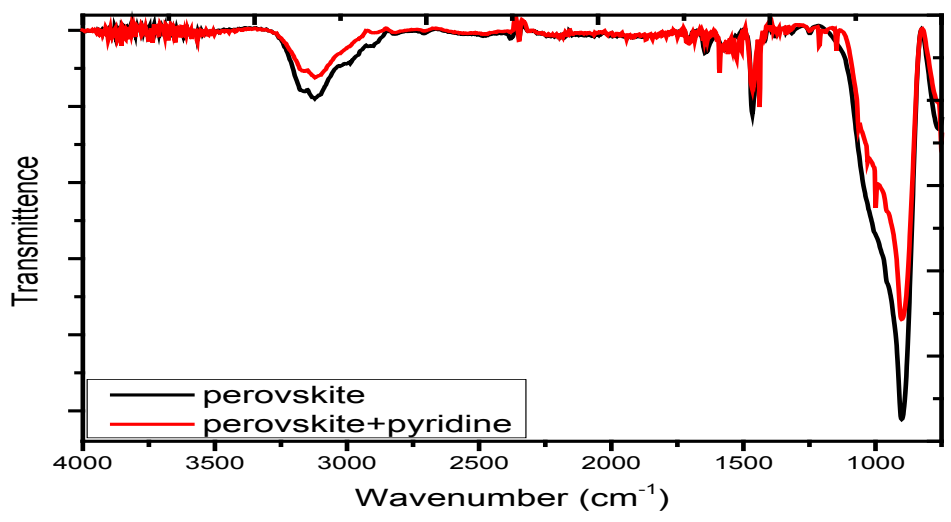

Fig. 3. FTIR spectrum of $\mathrm{CH}_{3} \mathrm{NH}_{3} \mathrm{PbI}_{3}$ before (black line) and after (red line) treatment with pyridine vapor in the region of $1750-4000 \mathrm{~cm}^{-1}$.

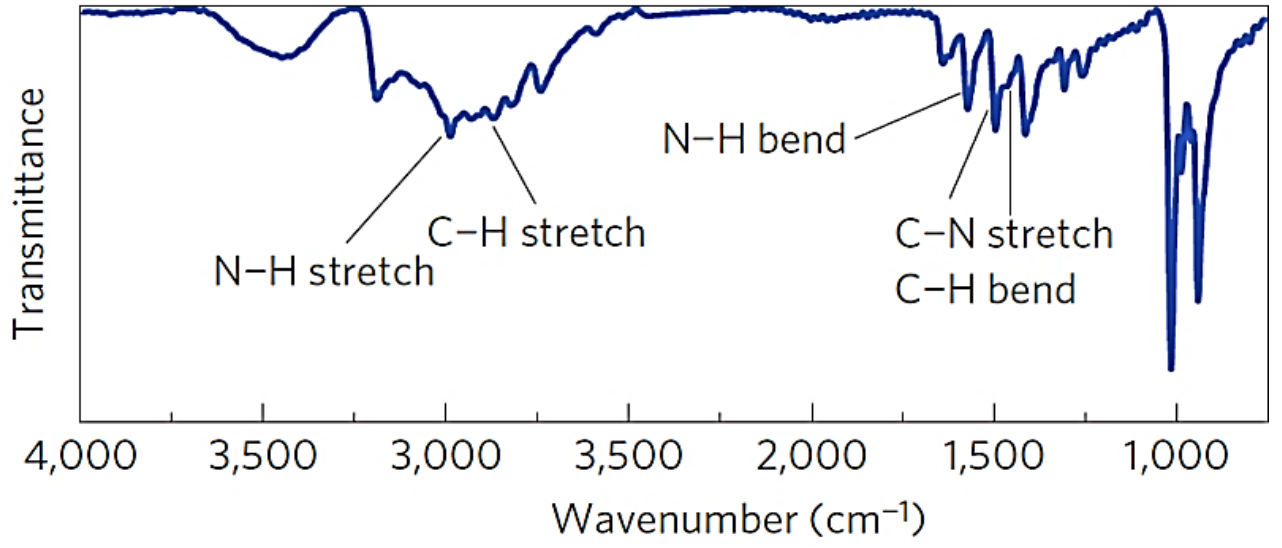

Fig. 4. FTIR spectrum of $\mathrm{CH}_{3} \mathrm{NH}_{3} \mathrm{PbI}_{3}$. [18]

Egypt. J. Chem. Special Issue (2019) 
Table 1 presents the values of characteristic oscillation frequencies of functional groups included in perovskite [19]. Peaks in the region of $1000 \mathrm{~cm}^{-1}$ are related to the vibrations of the DMFA solvent molecules (DMSO) in the composition of the perovskite solution.

After the perovskite film was treated with pyridine, new peaks appeared in the region of 1400-1600 $\mathrm{cm}^{-1}$ (Fig. 5a). A difference spectrum was constructed by subtracting the spectrum of the film of the original perovskite from the spectrum of the perovskite film treated with pyridine (Fig. 5 b).

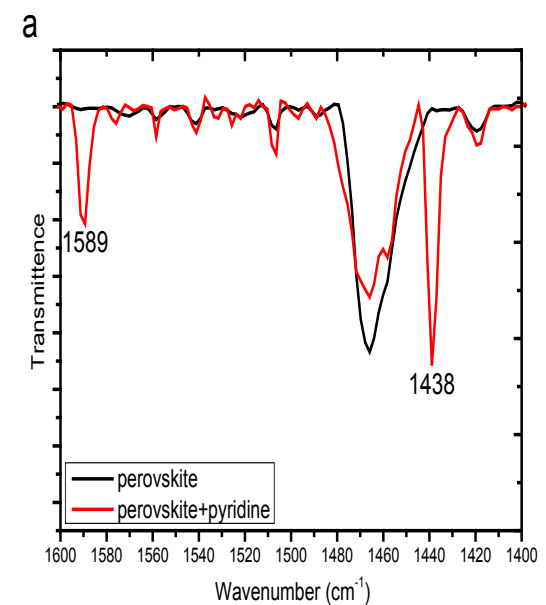

TABLE 1. Values of the characteristic oscillation frequencies of the perovskite functional groups of the composition $\mathrm{CH}_{3} \mathrm{NH}_{3} \mathrm{PbI}_{3}$.

\begin{tabular}{cl}
\hline $\begin{array}{c}\text { Wave number } \\
\left(\mathbf{c m}^{-1}\right)\end{array}$ & \multicolumn{1}{|c}{$\begin{array}{c}\text { Fluctuation } \\
\text { description }\end{array}$} \\
\hline 1450 & $\mathrm{C}-$ Hdeformation \\
1457 & N-Hdeformation \\
3030 & C-H valent \\
3080 & C-H valent, N-H \\
3124 & valent \\
3172 & N-H valent \\
N-H valent \\
\hline
\end{tabular}

b

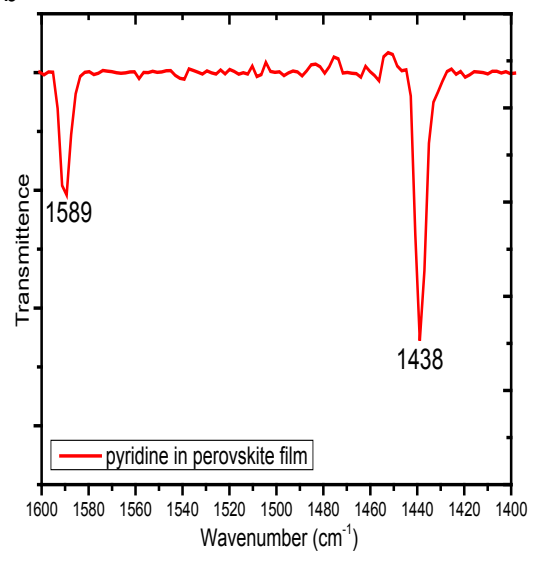

Fig. 5. a) FTIR spectrum of $\mathrm{CH}_{3} \mathrm{NH}_{3} \mathrm{PbI}_{3}$ before (black line) and after (red line) treatment with pyridine vapor in the region of $1400-1600 \mathrm{~cm}^{-1}$, b) difference FTIR spectrum.

The peak in the region of $1438 \mathrm{~cm}^{-1}$ most likely refers to asymmetric vibrations of the $\mathrm{CH}_{3}^{+}$group, and the peak in the region of 1589 $\mathrm{cm}^{-1}$ refers to vibrations of the aromatic ring [20]. Other peaks inherent in the vibrations of pyridine (900-1100 $\mathrm{cm}^{-1}$ ) overlap with the powerful peaks of the solvent DMFA (DMSO) in the composition of the perovskite solution.

\section{Conclusion}

The article presents the results of studies of perovskite films $\mathrm{CH}_{3} \mathrm{NH}_{3} \mathrm{PbI}_{3}$ before and after treatment with pyridine vapors. Characteristic absorption spectra and FTIR spectra indicate a slight change in the structure of perovskite films. However, no damage to the structure under the action of pyridine was detected, the material retained its semiconductor properties. The solution of the problem of increasing the longterm stability of organo-inorganic perovskites requires further research.

\section{References}

1. Miyasaka T., Park N-G., Grätzel M.; Organicinorganic halide perovskite photovoltaics, Springer, Switzerland (2016).

2. Song Zh., McElvany Ch., Phillips A.; A technoeconomic analysis of perovskite solar module manufacturing with low-cost materials and techniques, Energy Environ. Sci., 10, 1297-1305 (2017).

3. Chen Q., De Marco N., Yang Y.; Under the spotlight: The organic - inorganic hybrid halide perovskite for optoelectronic applications,Nano Today, 10, 355-396 (2015).

4. Zhou D., Zhou T., Tian Y; Perovskite-Based Solar Cells: Materials, Methods, and Future Perspectives, J.Nanomater.,2018, 1-15 (2018).

Egypt. J. Chem. Special Issue (2019) 
5. National Renewable Energy Laboratory (NREL), 2019, https://www.nrel.gov/pv/assets/pdfs/bestresearch-cell-efficiencies-190416.pdf, (access date: April 2019).

6. Berhe T.A., Su W-N., Chen Ch-Hs.; Organometal halide perovskite solar cells: degradation and stability, Energy Environ. Sci., 9, 323-356 (2016).

7. Saliba M., Matsui T., Seo J.-Y.; Cesium-containing Triple Cation Perovskite Solar Cells: Improved Stability, Reproducibility and High Efficiency, Energy Environ. Sci., 9, 1989-1997 (2016).

8. Gottesman R., Zaban A.; Perovskites for Photovoltaics in the Spotlight: Photoinduced Physical Changes and Their Implications, Acc. Chem. Res., 49, 320-329 (2016).

9. Yao Y., Wang G., Wu F.; The interface degradation of planar organic-inorganic perovskite solar cell traced by light beam induced current (LBIC), RSC Adv. 7, 42973-42978 (2017).

10. Noel N.K., Abate A., Stranks S.D., Parrott E.S., BurlakovV.M., Goriely A., Snaith H.J.; Enhanced Photoluminescence and Solar Cell Performance via Lewis Base Passivation of Organic-Inorganic Lead Halide Perovskites, ACS Nano, 8, 9815-9821 (2014).

11. Yang D., Yang R., Ren X.; Hysteresis-Suppressed High-Efficiency Flexible Perovskite Solar Cells Using Solid-State Ionic-Liquids for Effective Electron Transport, Adv. Mater., 28, 5206-5213 (2016).

12. Saliba M., Matsui T., Seo J-Y., Domanski K., Correa-Baena J-P., NazeeruddinM.K., Grätzel M.; Cesium-containing triple cation perovskite solar cells: improved stability, reproducibility and high efficiency, Energ. Environ. Sci., 9, 1989-1997 (2016).
13. Zhang T., Cheung S-H., Meng X.; Pinning Down the Anomalous Light Soaking Effect Towards High Performance and Fast Response Perovskite Solar Cells: The Ion-Migration Induced Charge Accumulation, J. Phys. Chem. Lett., 8, 5069-5076 (2017).

14. Yue Y., Salim N.T., Wu Y.; Enhanced stability of perovskite solar cells through corrosion-free pyridine derivatives in hole-transporting materials, Adv. Mater., 28, 10738-10743 (2016).

15. Joel J., Millet L.; Chemistry of heterocyclic compounds. $2^{\text {nd }}$ ed./Trans. from English F.V. Zaitseva and A.V. Karchava. - M.: Mir, 2004. $728 \mathrm{p}$.

16. Speranza M.; The reactivity of heteroaromatic compounds in gas phase, Adv. Heterocycl. Chem., 40, 25 (1986).

17. Arnett E.M., Chawla B.; Complete thermodynamic analysis of the hydration of thirteen pyridines and pyridinium ions. The special case of 2,6-di-tertbutylpyridine, J. Am. Chem. Soc., 101, 7141-7146 (1979).

18. Jeon N.J., Noh J.H., Kim Y.C., Yang W.S., Ryu S., Seok S.I.; Solvent engineering for highperformance inorganic-organic hybrid perovskite solar cells, Nat. Mater., 13, 897(2014).

19. Glaser T., Müller C., Sendner M., Krekeler C., SemoninO.E., Hull T.D., Lovrinčić R.; Infrared spectroscopic study of vibrational modes in methylammonium lead halide perovskites, J. Phys. Chem. Lett., 6, 2913-2918(2015).

20. Tarasevich B.N.; IR spectra of the main classes of organic compounds. Reference materials/B.N. Tarasevich - M.: MSU. Mv Lomonosov, 2012- 54 p. 
دراسه الخواص الضوئية للثرائح الرقيقة المحضرة من البيرفسكيت تحت تاثير ابخرة البيردين تاتيانا زيليناك'، فلاديسلاف كينيف'، سنيز انا فوكينا'، بافل جلادشيف' و مدحت ابراهير'

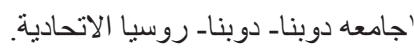

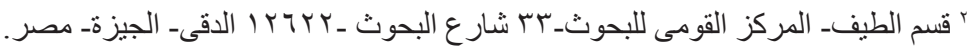

في الاونه الاخيرة أزداد الاعتماد علي مو اد البيرفسكيت في تصنيع الخلايا الثمسة مما ادي لارتفاع كفاءة الخلايا

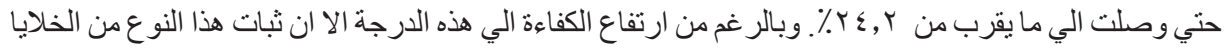

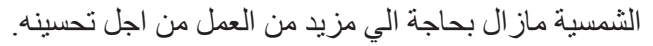

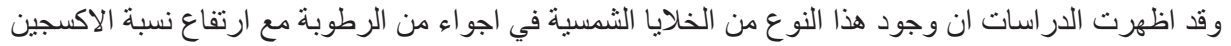

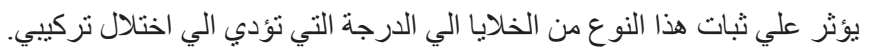

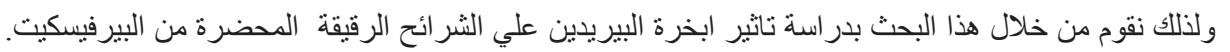

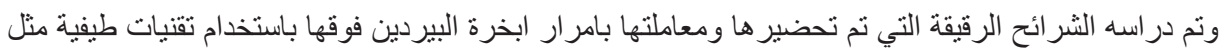

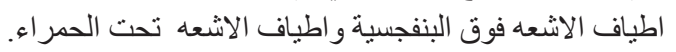

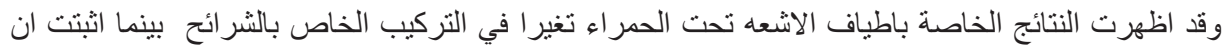

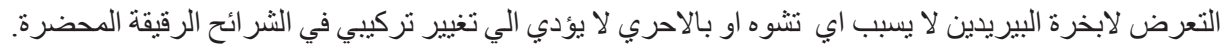

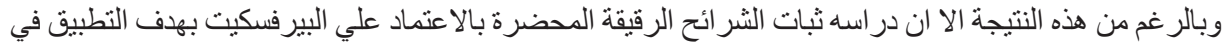

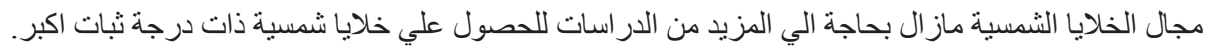

